\title{
Gender and Cool-Hot Executive Function as Moderators of Parenting and Attention Problems in Preschoolers: A Moderated Moderation Model
}

\author{
Jaehee $\mathrm{Kim}^{1}$, Jeeyoung $\mathrm{Noh}^{2}$ \\ Adjunct Professor, Department of Child and Family Studies, Yonsei University, Seoul, Korea ${ }^{1}$ \\ Ph. D., Department of Early Childhood Education, Gachon University, Seong-Nam, Korea ${ }^{2}$ \\ 부모양육과 유아의 주의집중 문제행동에 대한 유아의 성별과 \\ 인지적(cool) · 정서적(hot) 실행기능의 조절된 조절효과 \\ 김재희 ${ }^{1}$, 노지영 ${ }^{2}$ \\ 연세대학교 아동가족학과 겸임교수 ${ }^{1}$, 가천대학교 유아교육학과 박사 ${ }^{2}$
}

\begin{abstract}
Objectives: To increase specificity in the influence of children's characteristics when interacting with the environment, we aimed to test 1 ) whether gender has a moderating effect in the relationship between parenting behaviors and preschoolers' attention problems; and 2) whether this moderating effect varies by level of cool and hot Executive Function (EF).

Methods: A sample of 301 mothers and 4 to 6 year old children participated in the present study. Mothers reported on their parenting behaviors and their children's attention problems, and the children's executive function were assessed through behavioral tasks done by children. Data were analyzed using SPSS and PROCESS macro.

Results: The differential effects of parenting behaviors on children's attention problems depending on gender and levels of cool EF-hot EF were found. Limit-setting parenting behaviors were negatively associated with attention problems of girls with low levels of hot EF but, interestingly, positively associated with the attention problems among girls with high levels of cool EF. Whereas rejection/ neglectful parenting increased the attention problems of boys with low and medium levels of cool EF, rejection/neglectful parenting reduced the attention problems of girls with high levels of cool EF. Additionally, overprotective/permissive parenting behaviors increased the attention problems of girls with low levels of hot EF.

Conclusion: The present study suggests potential implications for theories and practices to better support parents in order to prevent children's attention problems during transition to school by understanding the differential susceptible effects of children's protective or vulnerable factors.
\end{abstract}

Keywords: parenting, cool-hot executive function, attention problems, moderated moderation, gender difference

\begin{abstract}
Introduction
초등학교 입학을 앞둔 유아에게 주의집중 능력은 학업적 수

Corresponding Author: Jeeyoung Noh, Ph. D., Department of Early Childhood Education, Gachon University, 1342 Seong-Nam-dairo, Sujeoung-gu Seong-Nam, Korea

E-mail: kidvill25@naver.com
\end{abstract}

행과 또래나 교사와의 긍정적인 관계 형성 등 적응적인 학교 생활을 하기 위해 갖추어야 하는 필수적인 요소이다 $(\mathrm{Kim} \&$ Jeon, 2013; Lan, Legare, Ponitz, \& Morrison, 2011). 주의력 결

CThe Korean Association of Child Studies

This is an Open Access article distributed under the terms of the Creative Commons Attribution Non-Commercial License (http:// creativecommons.org/licenses/by-nc/4.0) which permits unrestricted noncommercial use, distribution, and reproduction in any medium, provided the original work is properly cited. 
핍/과잉행동 장애 $(\mathrm{ADHD})$ 증상과 외현화 행동문제의 핵심 요 소인 주의집중 문제는(Achenbach \& Rescorla, 2000; Massetti et al., 2007; Rabiner \& Coie, 2000), 유아기에 발생되면 이후 시 기의 부적응 행동에 영향을 미칠 수 있어(Massetti et al., 2007; Rabiner \& Coie, 2000) 학교입학 이전에 예방하는 것이 중요할 것이다. 유아기의 주의집중 문제행동은 유아가 경험하는 대표 적인 환경인 부모의 양육행동과 유아 개인특성인 취약성 혹은 탄력성 등과 관련이 있다(Ellis \& Nigg, 2009; Hughes \& Ensor, 2009; Milich, Balentine, \& Lynam, 2001). 환경적 특성과 유전 적 특성의 상호작용에 대한 차별적 민감성 이론(differential susceptibility theory; Belsky, Bakermans-Kranenburg, \& van IJzendoorn, 2007)에 따르면, 개인의 특정 특성이 부정적인 환 경에 민감하게 반응하여 아동의 행동을 더욱 부정적으로 악화 시키기도 하고 혹은 긍정적인 환경에 민감하게 반응하여 아동 의 행동을 더욱 긍정적인 방향으로 촉진하는 방식으로 '더욱 나쁘게 혹은 더욱 좋게(for worse or for better)' 되는 상호작용 이 나타날 수 있다 (Belsky et al., 2007). 즉, 일상에서 반복되는 부모의 양육행동은 모든 유아에게 일반적으로 유사한 영향을 미치기도 하지만 간혹 유아의 특성이 특정 환경에 차별적으로 민감하게 반응하기도 하기에 같은 양육행동이라도 유아의 특 성에 따라 다른 영향을 미칠 수 있다(Belsky et al., 2007). 이러 한 맥락에서 유아의 주의집중 문제행동과 관련이 있다고 알려 진 유아 개인특성인 성별과 실행기능이 특정 양육행동과 어떻 게 상호작용하며 영향을 미치는지를 밝힘으로써 유아의 주의 집중 문제행동을 유발하는 메커니즘에 대해 기존에 조사된 연 구모형을 확장하여 다른 측면으로 조사될 필요가 있다.

또한, 유아의 중요한 환경인 부모는 자녀가 사회.정서적 인 기술을 습득하고 사회화하는데 중요한 역할을 하며, 부모 의 특정 양육행동의 영향은 자녀의 발달영역이 무엇인지에 따라 다른 양상으로 나타난다(Grusec \& Davidov, 2010). 따라 서, 부모양육의 하위영역을 따로 구분하지 않고 긍정적, 부정 적 혹은 부모의 양육행동으로 조사한 기존의 연구를 확장하 여 부모양육 각각의 하위요인 특성이 자녀의 주의집중 문제 행동에 어떻게 유의미한 영향을 주는지 세분화하여 살펴봄으 로써, 주의집중이라는 발달영역과 민감하게 작용하는 메커니 즘을 이해하는 노력이 필요하다(Grusec \& Davidov, 2010). 이 와 유사한 맥락에서, 몇몇 연구에서 $\mathrm{ADHD}$ 아동의 주의력 결 핍 증상(Milich et al., 2001)을 유발하거나 더욱 악화시킬 수 있 는 부모의 구체적인 양육행동 실재에 초점을 두고 조사하였다 (Ellis \& Nigg, 2009). 그 결과, 부모가 비반응적이고 부족한 대 처기술을 보이며 비민주적인 양육행동을 보이는 경우에 자녀
의 주의력 결핍 현상을 악화시키는 것으로 나타났다(Keown \& Woodward, 2002). 또한, 주의집중 문제행동은 개입이나 감독 의 부재 등 부정적인 양육행동 중에서도 특히 비일관적인 훈 육과 관계하는 것으로 나타났으며(Ellis \& Nigg, 2009), 특히 거 부하고 제한하는 부모의 양육이 주의집중 문제와 관계하였다 (Olson, Bates, Sandy, \& Schilling, 2002). 이러한 선행연구를 통 해 특히 유아의 주의집중 문제에 민감하게 영향을 미치는 특 정 양육행동이 구분될 수 있음을 예측할 수 있다.

한편, 유아의 주의집중 문제에 영향을 미칠 수 있는 유아 개 인의 고유 특성인 성별과 실행기능(Executive Function [EF])은 앞서 살펴본 유아의 주요 환경인 양육행동과 상호작용하며 그 영향을 다르게 할 수 있다. 선행연구에서 부모의 양육행동 이 유아 문제행동에 미치는 영향은 유아의 성별에 따라 차이 가 나타나는 것으로 보고하고 있지만(Endendijk, Groeneveld, Bakermans-Kranenburg, \& Mesman, 2016), 부모의 구체적인 각 각의 양육행동과 유아의 다양한 문제행동 간의 관계에서의 성 차에 대한 정보는 아직 부족하고 비일관적이다. 부모의 양육 행동은 자녀의 성별에 따라 달라질 수 있다. 예를 들어, 남아집 단에서는 부모가 신체적인 통제나 강압적인 양육을 더 한다면 여아집단에서는 부모가 부드러운 통제와 지시 혹은 한계설정 과 같은 지도를 더 많이 하는 것으로 나타났다(Endendijk et al., 2016). 또한, 주의력 문제와 관련된 연구에서 8-10세에서 여 아들이 남아들에 비해서 더 나은 주의력을 보이는 것으로 나 타났지만(Barnett et al., 2007), 더 느린 주의력 반응을 보이기 도 하였으며(Riley et al., 2016), 성차가 나타나지 않기도 하였 다(Lange, Thamothara, Sferra, Ramos, \& Fields, 2014). 실행기능 과 관련하여서도 연구결과가 실행기능을 측정하는 방법에 따 라서 성차가 비일관적으로 나타나 해석의 주의가 필요하지만, 남아집단의 실행기능은 충동성이 두드러지고, 반응이 빠른 데 반해, 여아집단에서는 잦은 처벌을 회피하는 성향(전환능 력)과 더 높은 수준의 작업기억이 나타났다(Grisson \& Reyes, 2019). 또한, 부모의 양육행동이 아동의 다양한 적응행동(예: 외현화 문제행동)에 미치는 영향은 아동의 성별에 따라 달라 지는 현상이 나타났다(Ruiz-Ortiz, Braza, Carreras, \& Muñoz, 2017). 어머니의 강압적인 양육은 여아의 외현화 문제행동에 영향을 어머니의 허용적인 양육은 남아의 외현화 문제행동에 영향을 미치는 것으로 나타나 부모양육의 하위영역은 자녀의 성별에 따라서 문제행동에 미치는 영향이 다르게 나타남을 알 수 있다. 하지만, 다른 부모양육 하위영역에서는 남녀 차이가 나타나지 않는 등 비일관적인 결과가 나타났고, 성차에 의한 설명력이 낮아 다양한 연구대상과 연구모형에 따른 성차에 대 
한 다양한 이론적 근거가 마련될 필요가 있다.

또한, 함께 고려되어야 할 유아의 특성인 실행기능(EF)은 학교 전이 시기의 적응행동이나 정서발달과 관련이 깊은 보호 요인으로 알려져(Hughes \& Ensor, 2009) 국내에서도 점차 관 심이 높아지고 있다. 하지만, 유아의 주의집중 문제행동에 미 치는 영향에 초점을 두어 살펴보거나 양육환경과 상호작용 하여 환경의 영향을 조절하는 역할로 살펴본 연구는 드물다. 따라서, 본 연구에서는 실행기능이 유아의 취약성(위험요인) 혹은 탄력성(보호요인)으로서 어떠한 역할을 하는지 조사하 는 연구로 확장하고자 한다. 주의집중 문제행동과 관련이 높 은 실행기능은 목적달성을 위해 행동을 통제하고, 문제를 해 결해야 하는 상황에서 활성화되는 상위 인지기능이다(Beck, Schaefer, Pang, \& Carlson, 2011). 목표를 설정하고 계획하며 의 사결정을 하는 과정에서 사고, 행동 및 정서를 조절하는 능력 이면서 인지적인 유연성을 의미한다(Diamond, 2013). 그런데 주의깊게 살펴볼 내용은 걸음마기와 유아를 대상으로 하는 실 행기능과 관련된 연구에서 유아의 실행기능은 두 가지의 축으 로 구분되어 나타난다는 점이다(Beck et al., 2011). 충동적인 반 응을 누르고 지연시키며 정서반응과 관련되는 충동 통제적인 정서적 실행기능(hot $\mathrm{EF})$ 과 정서적인 반응을 유발하지는 않지 만, 갈등 상황에 마주했을 때 적절하게 반응하는 갈등 통제적 인 인지적 실행기능 (cool EF)으로 구분될 수 있다. 인지적 실행 기능(cool EF)과 정서적 실행기능(hot $\mathrm{EF})$ 은 실행기능 개념의 연속선 상에서 양쪽 반대축에 위치하는 개념들이다. 따라서, 인지적 실행기능과 정서적 실행기능은 이 둘을 측정하는 실험 과제에서 활성화되는 뇌의 영역이 다르며, 아동의 연령, 지능, 기질, 언어능력 등과 다르게 관계하고(Zelazo \& Cunningham, 2007) 아동의 발달에 미치는 영향이 서로 다르게 나타나는 등 그 양상이 혼합된 비일관적인 연구결과를 보고하고 있다(Cole \& Deater-Deckard, 2009; Lan et al., 2011; Nigg, 2006). 실행기 능은 정서분화가 일어나고, 정서조절이 발달되기 시작하는 유 아기에 성숙되기 시작하는데, 어린 시기에는 인지적 실행기능 (cool EF)의 발달이 정서적 실행기능(hot $\mathrm{EF}$ )보다 성숙 속도가 더 느린 것으로 알려져 있다(Calson, 2005). 또한, 인지적 실행 기능(cool EF)은 주로 학업적 성취, $\mathrm{ADHD}$ 문제행동과 연관이 있고(Lan et al., 2011; Sonuga-Barke, Dalen, Daley, \& Remington, 2002), 정서적 실행기능(hot $\mathrm{EF}$ )은 정서와 관련되어 내면화 문 제행동과 외현화 문제행동과의 연관성이 두드러지게 나타난 다(Cole \& Deater-Deckard, 2009; Nigg, 2006). 이렇듯, 인지적 실행기능(cool $\mathrm{EF}$ )과 정서적 실행기능(hot $\mathrm{EF})$ 이 아동의 발달 영역에 서로 다른 영향을 미치는 것으로 알려져 있지만, 아직
은 정보가 부족한 실정이다. 더욱이 그동안 이루어진 실행기 능 관련 연구는 대부분 인지적 실행기능 (cool EF) 측면에 초점 을 두어 목표설정 과제를 어떻게 수행하는지를 조사해왔지만, 최근에는 점차 정서가 유발되고 동기가 활성화되는 상황에서 의 사고 과정 등을 내포하는 정서적 실행기능(hot $\mathrm{EF})$ 에 대한 관심이 높아지면서, 이를 구분해서 살펴보는 연구의 중요성이 강조되고 있는 추세이다(Tsermentseli \& Poland, 2016). 따라서, 인지적 실행기능과 정서적 실행기능의 성숙 속도에 차이가 있 는 유아기에 이 두 축을 구분하여 유아 특성을 고려하는 세분 화된 접근으로 이후 시기 학업성취나 학교적응을 방해할 수 있는 주의집중문제를 일으키는 원인에 대해 보다 상세한 정보 를 구하고자 한다.

또한, 선행연구에서 실행기능은 학교준비도, 학업성취 도와 사회적 행동발달에 대한 중요한 영향요인임이 밝혀 졌다(Brock, Rimm-Kaufman, Nathanson, \& Grimm, 2009; Willoughby, Kupersmidt, Voegler-Lee, \& Bryant, 2011). 그러나 유아기의 문제행동에 대한 실행기능의 영향력을 살펴본 연구 는 직접적 혹은 양육행동의 영향력에 대한 매개요인으로의 간접효과를 살펴보는 연구가 대부분이고(Ellis \& Nigg, 2009; Kamza et al., 2016), 부모의 양육행동이 유아의 문제행동에 미 치는 영향이 유아의 실행기능에 따라 어떻게 달라지는지 부 모 특성과 아동 특성을 모두 고려한 상호작용을 살펴본 연구 는 부족한 실정이다. 일부 연구에서 유아의 실행기능이 환경 의 부정적인 위험요소(예: 부모의 부정적인 강압적이고 개입 적인 양육)와 상호작용하여 그 부정적인 영향을 완충하며, 지 나친 반응이나 스트레스가 많은 경험을 통제하도록 돕는 보 호요인으로서의 역할을 하는 것으로 보고되었다(Gueron-Sela, Bedford, Wagner, \& Propper, 2018). 유사한 맥락에서 어머니 의 언어적 혹은 비언어적인 지도가 유아의 학습능력에 미치 는 영향이 유아의 실행기능(EF)에 따라 달라짐을 밝힌 연구 (Eason \& Ramani, 2017)에서 어머니의 능숙한 지도가 유아의 더 나은 학습능력에 미치는 영향은 유아의 실행기능이 낮을 때 유의미한 것으로 나타났고, 유아의 실행기능이 높을 때에 는 어머니의 지시적인 지도가 더욱 부정적인 영향을 미치는 것으로 나타났다. 또 다른 연구에서, 교사와 유아의 나쁜 관계 가 유아의 수학능력에 미치는 부정적인 영향은 유아의 실행 기능이 낮은 경우에 더욱 강해지는 것으로 보고되었고(Blair, Mc Kinnon, \& The Family Life Project Investigators, 2016), 중복 학대 경험과 유아의 외현화 문제행동 간의 관계는 실행기능 이 낮은 경우에만 나타났고, 실행기능이 평균수준 이상에서는 나타나지 않았다(Horn, Mc Kinnon, \& The Family Life Project 
Investigators, 2018). 인지적 실행기능(cool EF)의 전환능력이 나 작업기억 능력이 좋을 때는 같은 정도의 스트레스 상황에 서 부정적인 기분이나 문제에 덜 집중하고 조절하며, 반추사 고를 누르는 반응을 증가시키는 경향을 보인다(De Lissnyder, Koster, Derakshan, \& De Raedt, 2010; Hofmann, Schmeichel, \& Baddeley, 2012). 이 밖에도 유아의 실행기능(EF)이 조절변인으 로 사용된 선행연구들(Blair et al., 2016; Horn et al., 2018)을 통 해서 유아의 실행기능 성숙정도는 부모 양육행동의 영향을 더 욱 완충하거나 악화시키는 등 그 영향을 조절하는 역할을 할 것으로 예측된다.

선행연구의 고찰에 근거하여, 본 연구에서는 유아기의 주 의집중 문제행동에 대한 부모 양육행동의 영향력이 남아와 여 아집단에서 인지적 실행기능(cool EF)과 정서적 실행기능(hot $\mathrm{EF}$ ) 각각의 수준에 따라 그 양상이 어떻게 달라지는지 그 조절 된 조절효과를 조사하고자 하였다. 특히, 부모의 양육행동은 아동을 수용하고 애정적인 양육을 하는 ‘온정.격려', 규칙을 제 공하는 '한계설정', 아동을 통제하지 못하고 무조건 들어주는 '과보호·허용', 아이를 수용하지 못하고, 화내고 상호작용을 기 피하는 '거부.방임' 등 네 가지로 구분하여 각각의 영향을 조사 하였다. 따라서, 유아의 주의집중 문제행동에 더 민감하게 반 응하는 양육환경과 유아 개인의 특성(예: 성별, 인지적 실행기 능, 정서적 실행기능) 간의 조건 등을 구체적으로 조사하고자 한다. 이를 통해 유아의 주의집중 문제행동을 예방하기 위해 서 교육해야 하는 의미있는 양육행동은 무엇이고, 유아의 성 별에 따라 유아의 인지적 실행기능과 정서적 실행기능 발달 특성에 따라 어떻게 개별적으로 지원하는 것이 효과적일 수 있는지에 대한 근거를 마련해 학교입학을 준비하는 유아나 초 등학교 저학년의 부모를 대상으로 하는 중재예방 프로그램의
효과적인 방안을 제안하고자 한다.

본 연구에서 조사하고자 하는 연구문제는 다음과 같다.

\section{연구문제 1}

부모의 양육행동이 유아의 주의집중 문제행동에 미치는 영향 은 유아의 성별에 따라 조절되고, 이러한 효과는 다시 인지적 (cool)/ 정서적(hot) 실행기능에 따라 조절되는가?

\section{Methods}

\section{연구대상}

본 연구는 서울시와 경기도의 어린이집과 유치원을 편의표집 방법으로 선정하고 부모설문지와 유아가 직접 참여하는 측정 과제를 승인한 총 9기관에서 4-6세의 유아 301명과 그들의 어 머니를 대상으로 조사하였다. 연구대상인 유아의 평균연령은 5.62 세 $(S D=.81)$ 로 나타났으며 여아가 144 명(47.8\%), 남아가 157 명(52.2\%) 포함되었다. 어머니의 평균연령은 38세( $S D=$ $3.28)$ 이고, 어머니의 대부분이 4 년제 대학 졸업 이상 $(80.4 \%)$ 인 것으로 나타났다. 어머니의 대부분은 취업상태(74.8\%)였고, 회사원과 교사가 $43.5 \%$ 로 가장 높은 비율로 나타났으며, 전업 주부(25.2\%)와 기타 프리랜서(21.9\%)가 그 다음 순으로 나타 났다. 조사 가정의 월수입은 2019년 4인 가구 기준 중위소득 인 461.4만 원보다 높은 평균 약 635만 원 $(S D=251.29)$ 인 것으 로 나타났다.

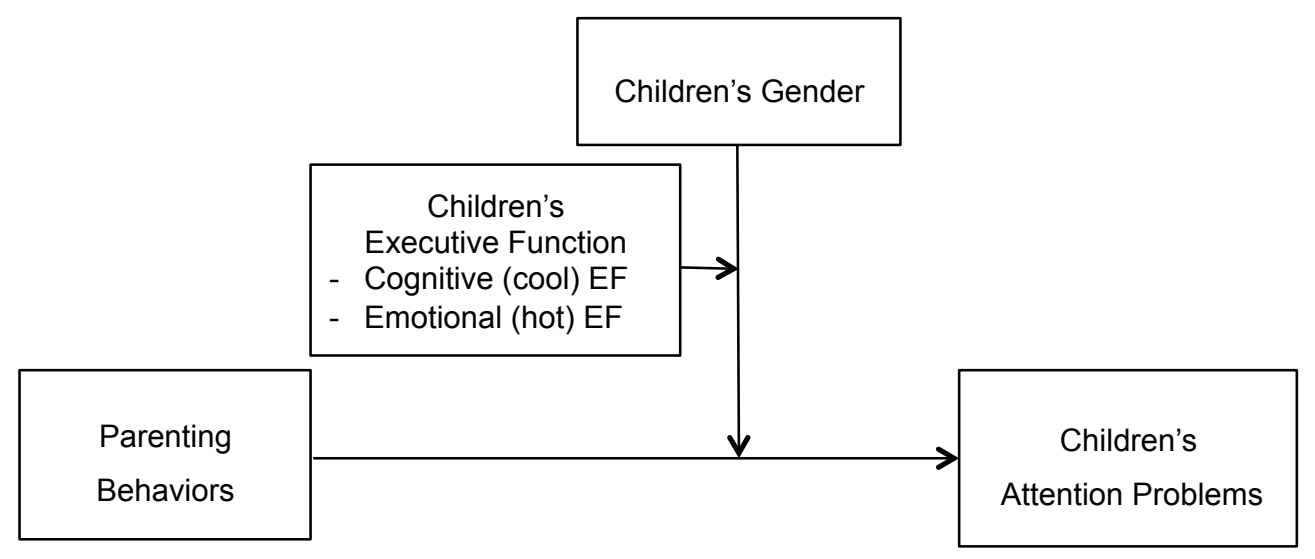

Figure 1. The hypothesized moderated moderation model. 
연구도구

\section{어머니의 양육행동}

어머니의 양육행동은 J. Park과 Rhee (2001)의 온정·격려(11문 항), 한계설정(8문항), 과보호.허용(7문항), 거부.방임(8문항) 등 4 개 하위요인의 총 34 문항으로 구성된 양육척도로 조사하 였다. 온정·격려는 아동을 수용해주고, 애정을 표현하며 필요 한 도움을 제공하고, 칭찬하며 격려하는 양육을 의미하며, "나 는 아이가 스스로 결정할 수 있는 기회를 항상 준다." 등의 문 항을 포함한다. 한계설정은 일상생활에서 규칙을 지키도록 하 고, 아동의 행동에 한계를 설정하여 지도하는 양육하는 행동 을 의미하며, "나는 아이가 정해진 시간에만 텔레비전을 보게 한다.” 등의 문항을 포함한다. 과보호.허용은 아동의 요구에 무조건 따르거나 아동에 대해 통제하지 못하는 양육행동을 의 미하며, "나는 아이가 가게에서 물건을 사달라고 조르면 대부 분 사준다.” 등의 문항을 포함한다. 마지막으로, 거부.방임은 아동을 수용하지 못하는 행동, 화를 내거나 신체적 체벌을 가 하는 행동과 아동의 의견을 무시하거나 상호작용을 기피하는 행동을 의미하며, 그 문항의 예는 “나는 아이가 조금만 잘못해 도 금방 화를 낸다.” 등이다. 모든 문항은 Likert식 5점 척도(전 혀 그렇지 않다[1점] 매우 그렇다[5점])로 측정되었고, 평균 을 구하여 분석에 사용하였으며 점수가 높을수록 각각의 양육 행동을 많이 하는 것을 의미한다. 문항 간 내적합치도는 온정. 격려가 .82 , 한계설정이 .72 , 과보호.허용이 .66 , 거부.방임이 .79로 나타났다.

\section{아동의 실행기능}

인지적 실행기능(cool executive function) 인지적 실행기 능(cool EF)을 측정하기 위해서 대표적으로 사용되는 Go-NoGo 과제의 하나인 적록신호(red-green signs) 과제(Murray \& Kochanska, 2002)를 사용하였다. 실험자는 아동을 마주하고, 실험자가 초록 깃발을 올리면 아동은 같은 방향의 손을, 빨강 깃발을 올리면 아동은 다른 방향의 손을 올리도록 지시하였 다. 초록 깃발 10 회, 빨강 깃발 10 회, 초록과 빨강 혼합 20 회를 시도하였다. 손을 잘못 들거나 모두 들거나 아무 손을 들지 않 으면 0점, 손을 잘못 들었다가 답을 다시 바르게 바꾸면 1점, 손을 들어 올리다가 다시 답을 바르게 바꾸면 2점, 바르게 손 을 들으면 3점으로 코딩하였다. 모든 과제 기회에 대한 점수를 합한 총점을 분석에 사용하였다. 관찰자 간 신뢰도는 1.00 으
로 나타났다.

정서적 실행기능(hot executive function) 정서적 실행기 능(hot EF)을 측정하기 위해서 Murray와 Kochanska (2002)가 사용한 간식지연(delay snacks)과제를 사용하였다. 실험실 안에 테이블과 의자 2 개를 마주보고 배치하고 사전조사로 선정한 유아가 좋아하는 보상물(초콜렛, 사탕, 캐러멜)을 투명한 접 시 안에 두고, 실험자가 종을 울릴 때까지 먹거나 가져가지 않 고, 책상 위 매트에 손을 올려두고 기다리는 과제이다. 10초, 20 초, 30 초, 15 초까지 기다리도록 총 4 회를 실행하고, 평균값 을 점수로 사용하였다. 종이 울리기 전에 먹거나 매번 시도에 서 반 정도까지 간 경우 0점부터, 종이 울린 다음에 간식을 먹 은 경우 7점까지 코딩하였다. 관찰자 간 신뢰도는 .99로 나타 났다.

\section{유아의 주의집중 문제행동}

유아의 주의집중 문제행동을 측정하기 위해서 Achenbach와 Rescorla (2000)가 개정하고 Oh와 Kim (2009)이 한국판으로 번 역한 부모평정용 $\mathrm{CBCL}$ 을 사용하였다. 본 연구에서는 유아의 주의집중 문제행동을 측정하는 5 문항 중 문항 간 상관관계가 음수이고, 문항 간 합치도를 낮추는 "이것하다 저것하다 행동 이 금방 바뀐다.”와 “운동신경이 좋지 않고 움직임이 어설프 다.” 2문항을 삭제하고, 3 문항만 분석에 포함하였다. 각 문항 은 3점 Likert식 척도로 0점 전혀 해당되지 않는다에서 2점 자 주 그런 일이 있거나 많이 그렇다로 응답하였고, 모든 문항의 점수는 합산되어 사용하였고, 점수가 높을수록 주의집중 문제 행동 수준이 높은 것을 의미한다. 문항 간 내적합치도는 .80 으 로 나타났다.

\section{연구절차}

본 연구는 2019년 2월부터 2019년 8월 중 수집된 자료를 사용 하였다. 먼저, 설문지 및 실행기능 검사의 적절성과 실험과제 의 훈련을 위해 경기도 소재의 유치원 1 곳 만 4 세 30 명과 그 부모를 대상으로 예비조사를 실시하였다. 본 조사에서는 설문 지와 유아가 직접 참여하여 관찰하는 실행기능 검사의 협조 를 동의한 기관을 섭외한 후, 연구 참여 동의를 받은 부모의 자 녀에게 부여한 ID가 부합되도록 기관에서 가정으로 밀봉 봉 투와 함께 부모설문지가 보내지고, 다시 밀봉된 설문지를 기 관으로 보내는 과정으로 자료를 수집하였다. 유아가 참여하 
는 실행기능 검사는 잠깐의 라포시간을 포함하여 총 10 분 정 도의 검사시간이 소요되었다. 부모와 아동에 소정의 답례품을 제공하였다. 설문지와 실행기능 검사에 참여한 총 352 명 중 설문지가 수거된 총 301 명만을 분석에 사용하였다.

\section{자료분석}

본 연구자료는 SPSS 25 (IBM Co., Armonk, NY)와 PROCESS macro (Hayes, 2017) 프로그램을 사용하여 분석하였다. 본 연 구모형은 PROCESS macro의 조절된 조절효과 모형(3번 모형) 을 사용하여 분석하였는데, 성별을 제 1 조절요인으로 실행기 능을 제 2 조절요인으로 설정하여 조절된 조절효과를 분석하였 다. 상호작용 효과의 통계적 유의미성은 Johnson-Neyman의 유의성 영역 검증을 통해 제시하였다. Johnson-Neyman 검증 은 상호작용 효과 검증 시 평균을 대푯값으로 선택하여 집단 을 구분하는 자의적인 방법에서 오는 한계와 오류를 보완하는 방법이다. 평균의 분포를 최소값과 최대값을 포함하는 임의의 23 개 특정값을 무작위적으로 추출하여 각 영역에서의 신뢰구 간을 알려주는 방식이다. 또한, 유의한 영역에 속하는 응답자 의 비율의 정보를 동시에 알려준다(Hayes, 2017).

\section{Results}

\section{기초분석}

본 분석에 앞서 이론적 근거를 통해 설정한 연구모형의 적절 성을 탐색하고, 가능한 통제변인들을 고려하기 위해 기초분석 을 실시하였다. 먼저, 사회인구학적 변인에 따른 조사변인의 평균차이를 살펴보기 위해서 $t$-test를 실시하고, 조사변인 간의 상관관계, 평균 및 표준편차를 구하여 그 경향성을 살펴보았 다. 그 결과, 어머니의 연령이 어머니의 온정·격려 양육행동, 거 부.방임, 유아의 주의집중 문제행동과 상관이 있는 것으로 나 타났다. 가정의 월수입은 어머니의 과보호.허용, 유아의 정서 적(hot) 실행기능과 유아의 주의집중 문제행동 $(r s=-.14 \sim .30$, $p<.05)$ 과 상관이 나타났다. 이와 같은 통계적인 근거와 모의 연령과 가정수입이 양육행동이나 유아의 실행기능과 상관이 있다고 보고한 선행연구(Blair et al., 2011; Bornstrein, Putnick, Suwalsky, \& Gini, 2006; Chico, Gonzalez, Ali, Steiner, \& Fleming, 2014)를 통해서, 본 연구에서는 어머니의 연령과 가정의 월수 입을 통제변인으로 설정하였다. 한편, 어머니의 한계설정 양
육행동 $(t=-5.29, p<.001)$, 인지적 (cool) 실행기능 $(t=-2.71, p<$ $.01)$, 유아의 주의집중 행동문제 $(t=-2.05, p<.05)$ 에서 여아가 남아보다 평균점수가 높은 것으로 나타나 성차를 확인하였다. 이를 통해서 본 연구에서 살펴보고자 하는 상호작용에 대한 성 별 차이를 보는 연구모형의 적절성을 확인하였다. 본 연구모형 에 포함된 조사변인들의 경향성을 살펴보면 Table 1 과 같다. 남 아의 경우에 어머니의 한계설정 양육행동은 남아의 주의집중 문제행동 $(r=-.28, p<.001)$ 과 부적으로, 과보호.허용 양육행동 은 남아의 인지적(cool) 실행기능 $(r=.18, p<.05)$ 과 정적으로, 거부.방임 양육행동은 남아의 인지적(cool) 실행기능 $(r=.29, p$ <.001)과 주의집중 문제행동 $(r=.33, p<.001)$ 과 정적으로 상관 이 나타났다. 남아의 인지적 실행기능(cool EF)과 정서적 실행 기능(hot $\mathrm{EF})$ 은 .19 ( $p$ < .05)의 정적 상관이 나타났다. 반면에, 여아의 경우에 어머니의 온정·격려 양육행동은 여아의 주의집 중 문제행동 $(r=.24, p<.01)$ 과 정적으로, 과보호.허용 양육행 동은 인지적(cool) 실행기능 $(r=-.23, p<.01)$ 과 부적으로, 거부. 방임 양육행동은 인지적(cool) 실행기능 $(r=.26, p<.01)$ 과 정적 으로 상관이 나타났다. 유아의 인지적(cool) 실행기능과 정서적 (hot) 실행기능 간에는 정적상관 $(r=.33, p<.001)$ 이 나타났고, 유아의 인지적(cool) 실행기능과 유아의 주의집중 문제행동 간 에도 정적상관 $(r=.29, p<.01)$ 이 나타났다. 이와 같은 결과를 통해서, 어머니의 각 양육행동의 하위영역별로 유아의 실행기 능에 다른 양상으로 영향을 미칠 수 있음을 예측하였고, 유아 의 주의집중 문제행동에 대한 어머니의 양육행동과 실행기능 의 주효과가 나타나지 않을 수 있음을 예측하여 본 분석을 통 해서 상호작용 효과의 검증을 하고자 하였다. 또한, 남아집단 과 여아집단별로 각 조사변인들의 관계성이 차이가 나타남에 따라 집단 간 차이를 예측하였다. 각 변인들의 평균·표준편차 와 왜도.첨도는 Table 2에 제시하였다.

\section{유아의 주의집중 문제행동에 대한 어머니의 양육행동, 성별 및 인지적 $(\operatorname{cool~EF)/ㅈㅓㅇㅅㅓㅈㅓㄱ~}$ (hot $\mathrm{EF)}$ 실행기능의 조절된 조절효과}

본 연구에서는 어머니의 각 하위유형별 양육행동이 유아의 주의집중 문제행동에 미치는 영향은 성별과 유아의 인지적 (cool) 그리고 정서적(hot) 실행기능 수준에 따라 어떻게 달라 지는지 각각의 3 원 상호작용을 살펴보고자 하였다. 이러한 조 절된 조절효과를 조사하기 위해서, PROCESS macro의 3번 모 형을 통해 여러 개의 모형을 반복하여 분석하였다. 즉, 각 하 위요인별 어머니의 양육행동 $(\mathrm{X})$ 이 유아의 주의집중 문제행동 


\section{Moderated Moderation Effects on Attention Problems}

Table 1

Bivariate Correlations Among Parenting, Cool and Hot EF and Children's Attention Problems in Boys and Girls

\begin{tabular}{|c|c|c|c|c|c|c|c|}
\hline & 1 & 2 & 3 & 4 & 5 & 6 & 7 \\
\hline \multicolumn{8}{|l|}{ Parenting } \\
\hline 1. Warm/Encourage & - & $.60^{* * *}$ & $-.24^{* *}$ & $-.43^{* * *}$ & .03 & .12 & $.24^{* *}$ \\
\hline 3. Overprotective/Permissive & $-.19^{*}$ & $-.41^{* * *}$ & - & .11 & -.15 & $-.23^{* *}$ & .11 \\
\hline 4. Rejection/Neglectful child's executive function & $-.70^{* * *}$ & $-.33^{* * *}$ & -.05 & - & .14 & $.26^{* *}$ & -.08 \\
\hline 6. Cool executive function & -.13 & -.03 & $.18^{*}$ & $.29^{* * *}$ & $.19^{*}$ & - & $.29^{* *}$ \\
\hline 7. Child's attention problem & -.11 & $-.28^{* * *}$ & -.05 & $.33^{* * *}$ & -.09 & -.10 & \\
\hline
\end{tabular}

Note. Boys $N=157$; Girls $N=144$.

Boys' estimates in bottom triangle; Girls' estimates in upper triangle.

${ }^{*} p<.05 .{ }^{* *} p<.01 .{ }^{* * *} p<.001$.

Table 2

Mean, Standardized Deviation, Skewness, and Kurtosis of All Variables in Boys and Girls

\begin{tabular}{|c|c|c|c|c|c|c|c|c|}
\hline & \multicolumn{4}{|c|}{ Boys $(N=157)$} & \multicolumn{4}{|c|}{ Girls $(N=144)$} \\
\hline & Mean & $S D$ & Skewness & Kurtosis & Mean & $S D$ & Skewness & Kurtosis \\
\hline \multicolumn{9}{|l|}{ Parenting } \\
\hline 1. Warm/Encourage & 3.81 & .42 & .24 & -.85 & 3.89 & .40 & -.02 & .14 \\
\hline 2. Limit-setting & 3.45 & .45 & .34 & .19 & 3.75 & .53 & -.45 & -.45 \\
\hline 3. Overprotective/Permissive & 2.16 & .38 & -.03 & .89 & 2.25 & .58 & -.23 & -1.03 \\
\hline 4. Rejection/Neglectful child's executive function & 2.62 & .65 & -.50 & -.10 & 2.73 & .53 & .70 & 1.37 \\
\hline 5. Hot executive function & 23.40 & 6.55 & -1.47 & 1.28 & 23.72 & 6.80 & -1.60 & 1.39 \\
\hline 6. Cool executive function & 42.17 & 7.61 & -.75 & -.41 & 44.20 & 5.29 & -.66 & -.82 \\
\hline 7. Child's attention problem & .60 & .89 & 2.07 & 7.93 & .92 & 1.62 & 2.18 & 4.01 \\
\hline
\end{tabular}

Note. Boys $N=157$; Girls $N=144$.

(Y)에 미치는 영향을 제 1 조절변인인 성별(M)이 조절하는데 $(2$ 원 상호작용), 제2조절변인인 인지적(cool) 혹은 정서적(hot) 실행기능이 2원 상호작용을 어떻게 조절하는지에 대한 조절 된 조절효과를 조사하였다. 이때, 사전분석에서 고려한 어머 니의 연령과 가정수입을 통제하고 분석하였다. 조절된 조절 효과의 3 원 상호작용은 $\mathrm{X} \rightarrow \mathrm{Y}$ 의 계수, $\mathrm{X} \times \mathrm{W}$ (제1조절변인) 의 계수와 $\mathrm{X} \times \mathrm{W} \times \mathrm{Z}$ 의 계수가 음인지 양인지의 조합에 따라 조절된 조절효과의 유형이 8 가지로 구분된 해석이 가능하다 (Hayes, 2017).

조절된 조절효과를 분석한 결과, 어머니의 한계설정과 유 아의 정서적(hot) 실행기능을 포함하는 모형, 과보호·허용 양 육행동과 유아의 정서적(hot) 실행기능을 포함하는 모형, 어 머니의 한계설정과 인지적(cool) 실행기능을 포함하는 모형 과 거부.방임 양육행동과 인지적 $(\mathrm{cool})$ 실행기능을 포함하는 모형에서만 유의미한 3원 상호작용이 나타났다. 어머니의 한
계설정 양육행동, 성별 및 유아의 인지적(cool) 실행기능의 모형과 어머니의 과보호.허용 양육행동, 성별 및 유아의 정 서적(hot) 실행기능의 모형은 B유형의 조절효과로 나타났다 (Hayes, 2017). 어머니의 거부.방임 양육행동, 성별 및 유아의 인지적 $(\mathrm{cool})$ 실행기능의 모형과 어머니의 한계설정 양육행 동, 성별 및 유아의 정서적(hot) 실행기능의 모형은 G유형의 조절효과로 나타났다(Hayes, 2018). B유형의 조절된 조절효과 는 $\mathrm{X} \rightarrow \mathrm{Y}$ 의 계수가 양수 $(+), 2$ 원 상호작용 $(\mathrm{X} \times \mathrm{W})$ 의 계수가 음수(-)이고 3 원 상호항 $(\mathrm{X} \times \mathrm{W} \times \mathrm{Z})$ 의 계수가 양수(+)이다. $\mathrm{B}$ 유형은 $\mathrm{X}$ 가 증가하면 $\mathrm{Y}$ 가 증가하는데, 제 1 조절변인(W)이 증 가하면 그 효과의 증가폭이 감소되는 완충효과가 나타나며 제 2조절변인 $(\mathrm{Z})$ 가 증가되면 이러한 완충효과가 줄어드는 현상 으로 해석한다. 반면에, $\mathrm{G}$ 유형의 조절된 조절효과는 $\mathrm{X} \rightarrow \mathrm{Y}$ 의 계수가 음수 $(-), 2$ 원 상호작용 $(\mathrm{X} \times \mathrm{W})$ 의 계수가 양수(+)이고, 3 원 상호항 $(\mathrm{X} \times \mathrm{W} \times \mathrm{Z})$ 의 계수가 음수(-)이다. G유형은 $\mathrm{X}$ 가 증 
가하면 Y가 감소하며 제 1 조절변인인 W가 증가될수록 이러한 감소현상이 완충된다(+). 또한, 제 2 조절변인인 $\mathrm{Z}$ 가 증가하면 이러한 감소되는 완충현상이 감소(-)하는 것으로 해석한다. 구체적으로 그 결과를 살펴보면 다음과 같다.

\section{유아의 주의집중 문제행동에 대한 어머니의 양육행동, 성별과 인지적(cool EF) 실행기능의 조절된 조절효과}

어머니의 한계설정 양육행동, 성별과 인지적 (cool EF) 실행기능의 3원 상호작용

유아의 인지적(cool) 실행기능을 제 2 조절변인으로 포함하는 모형을 살펴보면 다음과 같다. 먼저, 어머니의 연령과 가정수 입을 통제한 후, 어머니의 한계설정 양육행동은 유아의 주의 집중 문제행동에 정적 영향을 미쳤다 $(B=9.76, p<.01)$. 어머 니의 한계설정이 유아의 주의집중 문제행동에 미치는 영향을 유아의 성별이 조절하는 2 원 상호작용은 부적방향으로 나타 났다 $(B=-8.32, p<.01)$. 어머니가 한계설정 양육행동을 많이 할수록 주의집중 문제행동이 증가하는 현상은 여아일수록 그
증가폭이 줄어드는 완충효과가 나타났다. 그러나, 여아의 인 지적(cool) 실행기능이 높아질수록 그 완충효과 현상은 감소 하는 3 원 상호작용이 나타났다 $(B=.20, p<.01)$. 즉, 어머니의 한계설정 양육행동이 증가할수록 주의집중 문제행동이 증가 하는 현상은 여아에게서는 완화되지만, 여아의 인지적 실행기 능이 높을 때는 다시 증가된다. 한계설정 양육행동이 이러한 조절된 조절효과의 효과는 $3 \%$ 의 설명력을 갖는 것으로 나타 났다. 즉, 인지적(cool) 실행기능이 높은 여아 집단에서 이러한 3 원 상호작용이 유의미한 것으로 나타났다 $(B=1.00, p<.001)$. Johnson-Neyman의 유의미성 검증에 의하면, Figure 2에서 나 타나는 한계설정 양육행동이 주의집중 문제행동을 증가시키 는 현상은 인지적 $(\mathrm{cool})$ 실행기능의 점수가 31.44 보다 작거나 (전체 응답자 중 하위 $8.49 \%$ 해당) 44.59 보다 큰 영역(전체 응 답자 중 상위 $54.24 \%$ 해당)에서만 유의한 것으로 나타났다.

어머니의 거부·방임 양육행동, 성별과 인지적 $(\operatorname{cool~EF})$ 실행기능의 3 원 상호작용

다음으로, 어머니의 연령과 가정수입을 통제한 후에 어머니 의 거부. 방임 양육행동의 유아의 주의집중 문제행동에 대한

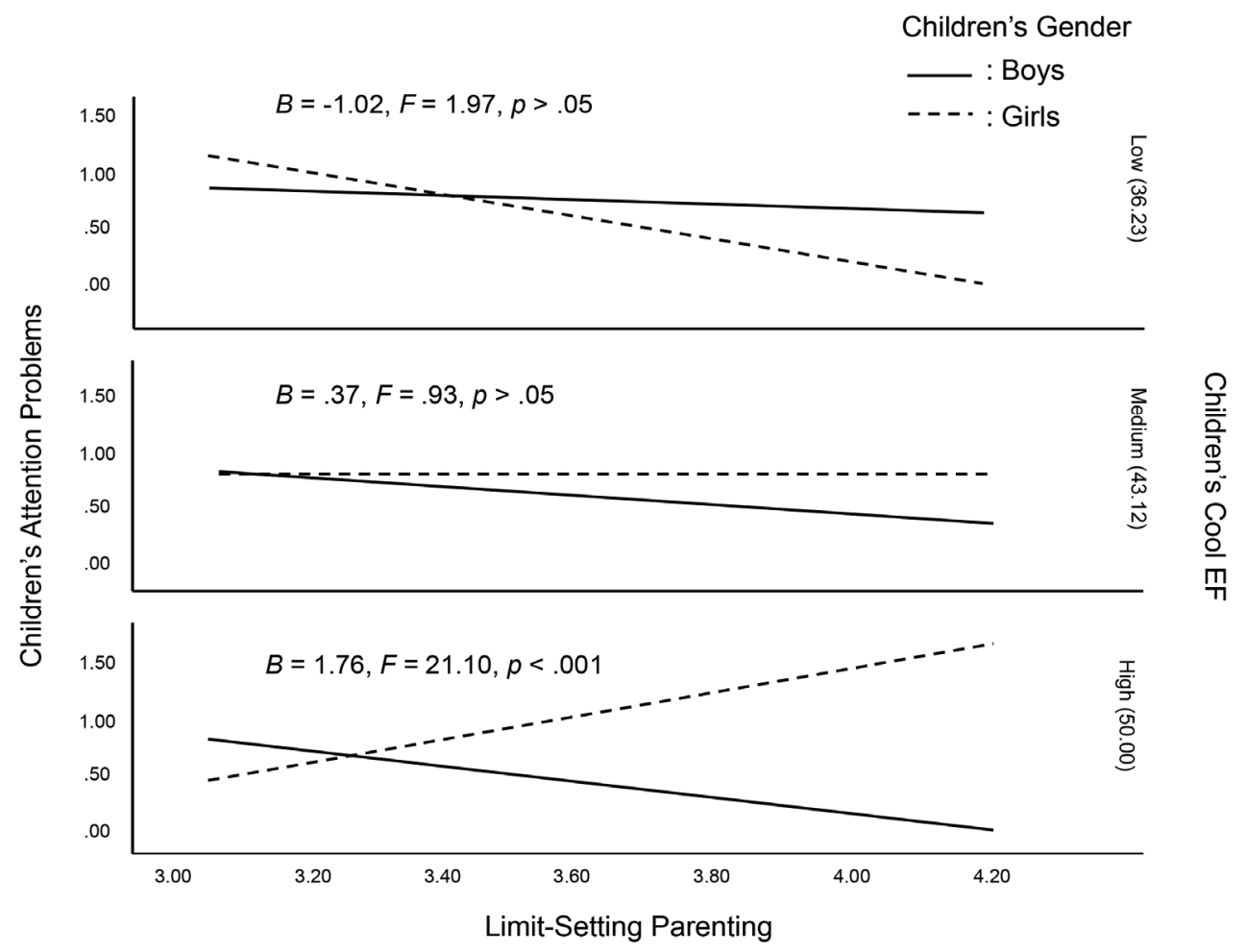

Figure 2. The moderating effect of gender between limit-setting parenting and attention problems among the different levels of cool executive function. 
영향은 유의미하지 않았다 $(B=-2.96, p>.01)$. 어머니의 거부. 방임양육의 유아의 주의집중 문제행동에 미치는 영향을 유아 의 성별이 조절하는 2 원 상호작용은 유의미하지 않았지만 $(B=$ $3.62, p>.01)$, 이러한 2원 상호작용을 유아의 인지적(cool) 실 행기능이 조절하는 3 원 상호작용은 유의미한 것으로 나타났 다 $(B=-.10, p<.05)$. 어머니의 거부.방임이 증가할수록 주의집 중 문제행동이 감소되는 현상은 여아일수록 그 감소폭이 줄어 드는 완충효과가 나타났다. 그러나, 유아의 인지적(cool) 실행 기능이 증가될수록 그 완충효과 현상이 감소되는 3 원 상호작 용이 나타났다. 어머니의 거부.방임 양육행동이 주의집중 문 제행동을 감소시키는 현상은 여아집단에서 완충되지만, 여아 의 인지적(실행기능)이 높으면 거부.방임을 할수록 주의집중 문제행동이 줄어드는 현상이 강해지는 것으로 나타났다. 더 구체적으로는, 인지적(cool) 실행기능이 높은 여아 집단에서 $(B$ $=-1.08, p<.001)$ 와 인지적 $(\mathrm{cool})$ 실행기능이 낮은 남아집단 $(B$ $=.46, p<.05)$ 과 실행기능이 중간인 남아집단 $(B=.42, p<.05)$ 에서 3 원 상호작용이 유의미한 것으로 나타났다. 이러한 조절 된 조절효과의 효과는 $1 \%$ 의 설명력을 갖는 것으로 나타났다. Johnson-Neyman의 유의미성 검증에 의하면, Figure 3에서 나
타난 거부.방임이 주의집중 문제행동을 줄이는 현상은 인지 적 $(\mathrm{cool})$ 실행기능의 평균점수가 41.41보다 큰 영역(전체 응답 자 중 상위 $66.42 \%$ 해당)에서 유의미한 것으로 나타났다.

\section{유아의 주의집중 문제행동에 대한 어머니의 양육행동, 정서적 $(h o t \mathrm{EF})$ 실행기능과 성별 의 조절된 조절효과}

어머니의 한계설정 양육행동, 성별과 정서적 (hot $\mathrm{EF}$ ) 실행기능의 3원 상호작용

유아의 정서적(hot) 실행기능을 제 2 조절변인으로 포함하는 모 형을 살펴보면 다음과 같다. 어머니의 한계설정 양육행동이 유아의 주의집중 문제행동에 부적영향을 미치는 것으로 나타 났다 $(B=-6.23, p<.01)$. 어머니의 한계설정이 유아의 주의집 중 문제행동에 미치는 영향을 유아의 성별이 조절하는 2 원 상 호작용은 정적 방향으로 나타났다 $(B=4.85, p<.01)$. 유아의 정서적(hot) 실행기능을 고려한 연구모형에서는 어머니의 한 계설정이 증가할수록 주의집중 문제행동이 감소되는데, 여아

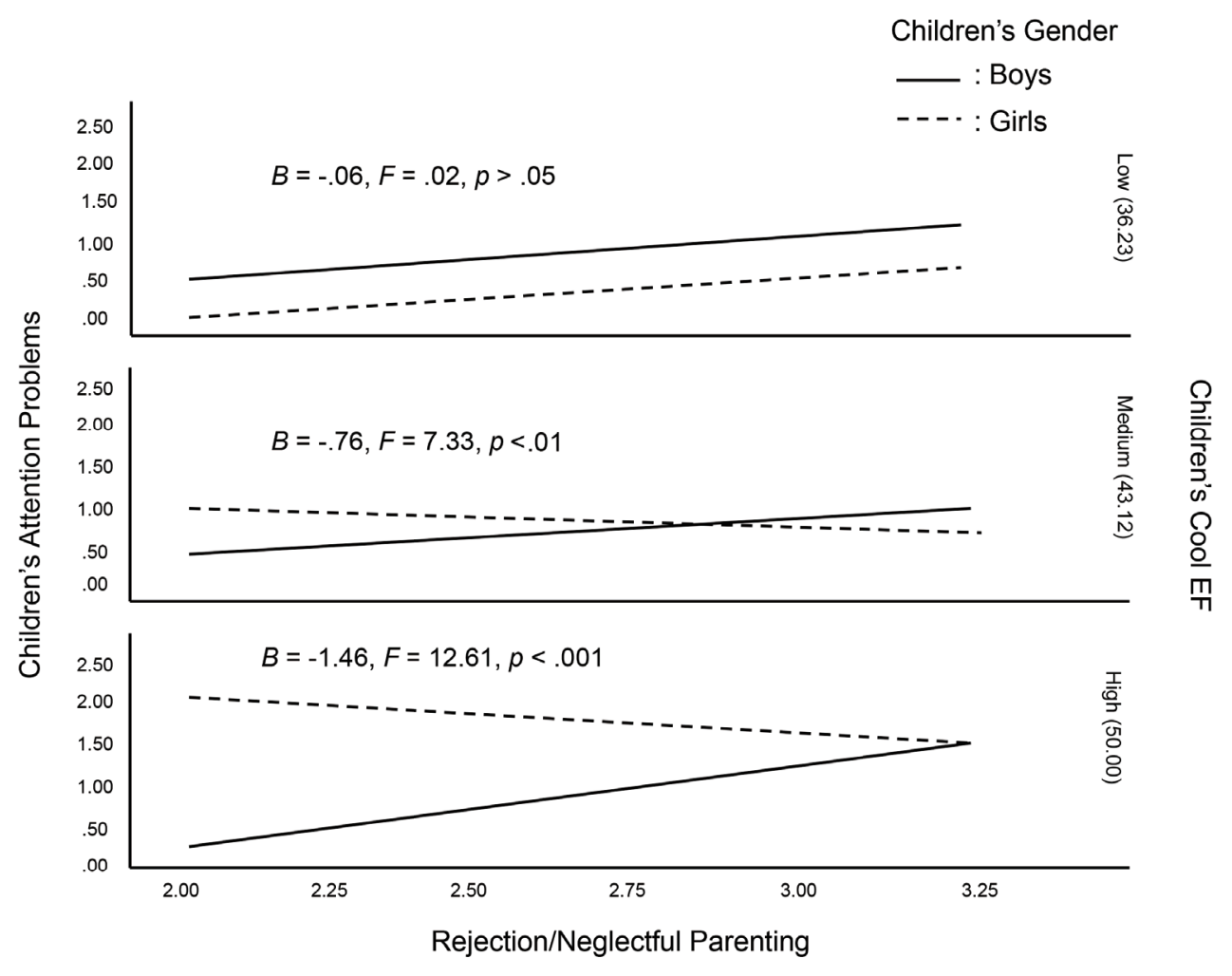

Figure 3. The moderating effect of gender between rejection/neglectful parenting and attention problems among the different levels of cool executive function. 


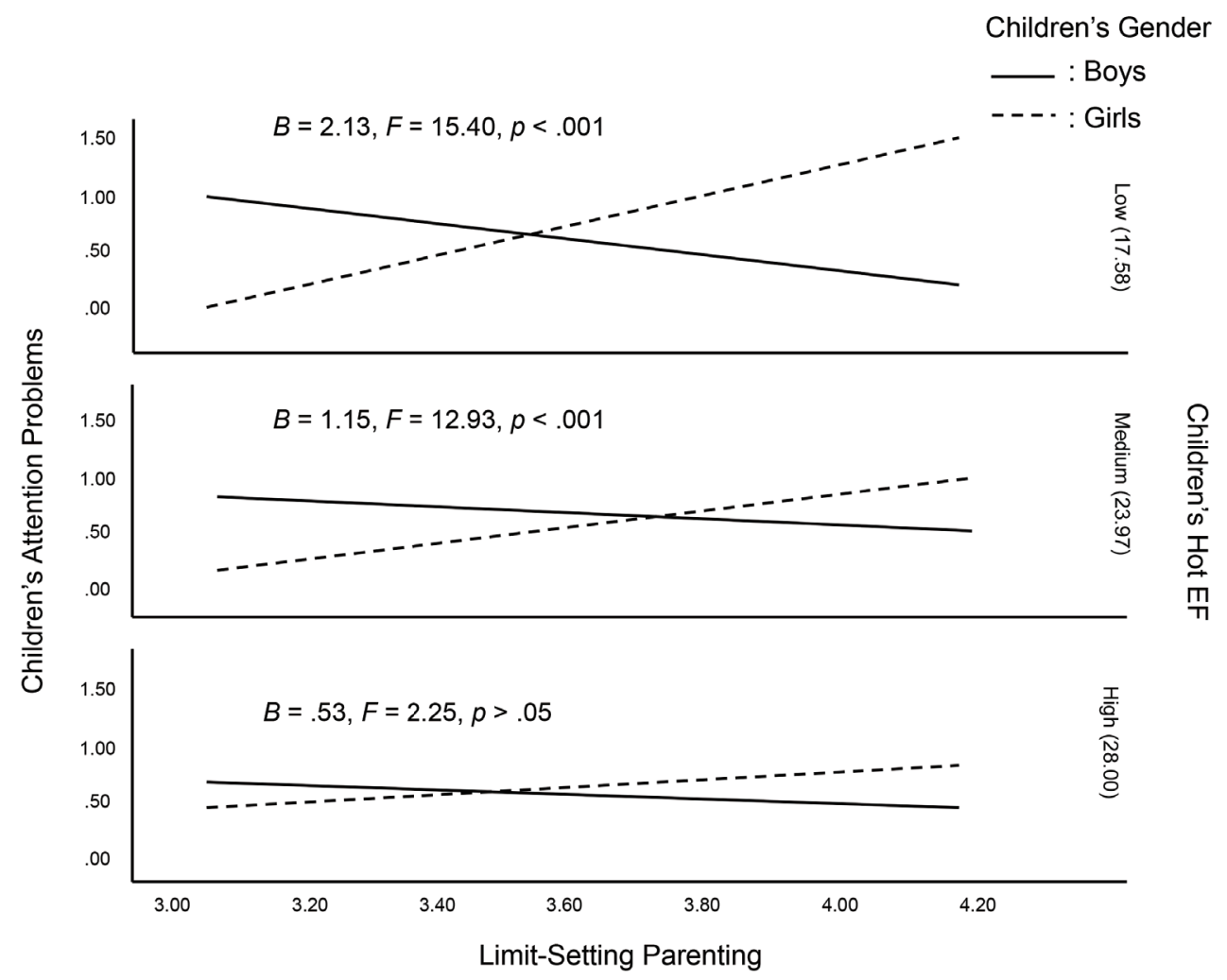

Figure 4. The moderating effect of gender between limit-setting parenting and attention problems among the different levels of hot executive function.

집단에서는 한계설정이 주의집중 문제행동을 줄이는 감소폭 을 감소시키는 완충효과가 나타났다. 그러나, 유아의 정서적 (hot) 실행기능이 높으면, 이러한 부정적인 완충현상을 감소시 키는 3원 상호작용이 나타났다 $(B=-.15, p<.01)$. 한계설정 양 육행동이 주의집중 문제행동을 완화하는 긍정적인 효과가 여 아일 때에는 줄어들지만, 여아의 정서적(hot) 실행기능이 높아 질수록 한계설정 양육행동의 긍정적인 영향력이 다시 강화되 는 것으로 나타났다. 특히, 남아집단에서 정서적(hot) 실행기 능이 낮은 경우 $(B=-.62, p<.01)$ 와 여아집단에서 정서적(hot) 실행기능이 낮은 경우 $(B=1.51, p<.01)$ 와 중간 정도인 경우 $(B$ $=.80, p<.001)$ 에서 3 원 상호작용이 유의미하게 나타났다. 조 절된 조절효과의 효과는 $2 \%$ 의 설명력을 갖는 것으로 나타났 다. Johnson-Neyman의 유의미성 검증에 의하면, Figure 4에서 나타나는 한계설정 양육행동이 주의집중 문제행동을 줄어들 게 하는 현상은 정서적(hot $\mathrm{EF})$ 실행기능의 평균점수가 27.18 보다 작은 영역에서만(전체 응답자 중 하위 $41.33 \%$ 해당) 유 의미한 것으로 나타났다.
어머니의 과보호 - 허용 양육행동과 성별 및 정서적(hot $\mathrm{EF})$ 실행기능의 3원 상호작용

어머니의 과보호. 허용 양육행동은 유아의 주의집중 문제행 동에 정적영향을 미치는 것으로 나타났다 $(B=4.17, p<.05)$. 어머니의 과보호. 허용이 유아의 주의집중 문제행동에 미치 는 영향을 유아의 성별이 조절하는 2원 상호작용은 부적인 방 향으로 유의미하게 나타났다 $(B=-2.77, p<.05)$. 어머니의 과 보호.허용이 증가할수록 주의집중 문제행동이 증가되는 현상 은 여아일수록 과보호.허용의 부정적인 영향의 증가폭을 감소 시키는 완충효과가 나타났다. 그러나, 여아의 정서적(hot) 실 행기능이 높으면, 그 완충효과 현상이 감소되는 3 원 상호작용 이 나타났다 $(B=.13, p<.01)$. 과보호 - 허용 양육행동이 주의 집중 문제행동에 미치는 부정적인 영향은 여아의 경우 덜하지 만, 여아의 정서적(hot) 실행기능이 높을 때에는 과보호 - 허용 이 주의집중 문제행동에 미치는 영향이 강해지는 것으로 나타 났다. 특히, 여아집단에서 정서적(hot) 실행기능이 높은 수준 일 때에 3 원상호작용이 유의미한 것으로 나타났다 $(B=.65, p$ <.01). 이러한 조절된 조절효과의 효과는 $2 \%$ 의 설명력을 갖는 


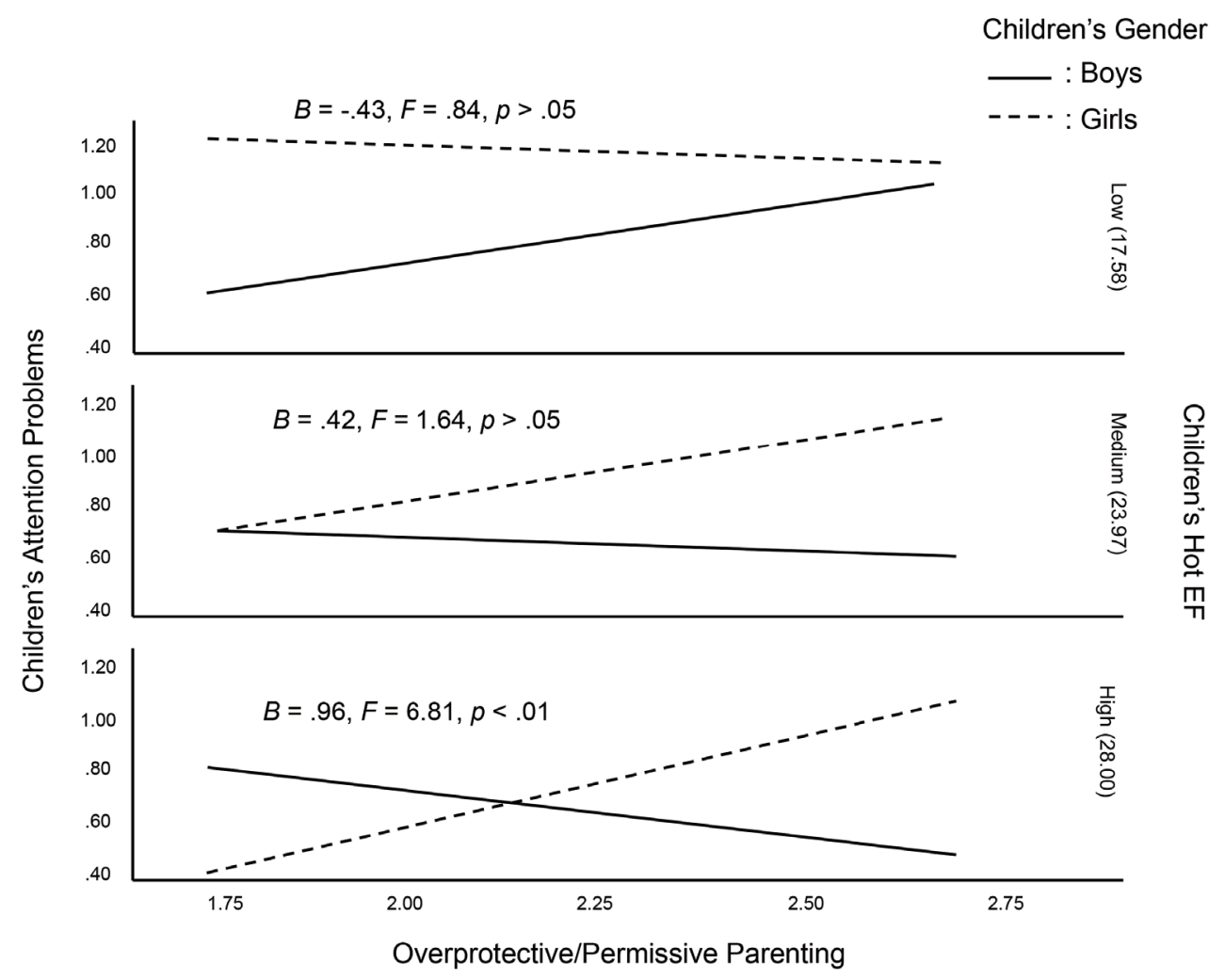

Figure 5. The moderating effect of gender between overprotective/permissive parenting and attention problems among the different levels of hot executive function.

것으로 나타났다. Johnson-Neyman의 유의미성 검증에 의하 면, Figure 5에서 나타나는 현상은 정서적(cool) 실행기능의 평 균점수가 8.09 보다 작거나(전체 응답자 중 하위 $7.38 \%$ 해당) 25.72 보다 큰 영역(전체 응답자 중 상위 $58.67 \%$ 해당)에서만 유의한 것으로 나타났다.

\section{Discussion}

본 연구는 유아의 주의집중 문제행동에 대한 어머니의 양육유 형의 영향이 유아의 성별과 인지적(cool EF)/정서적(hot $\mathrm{EF})$ 실 행기능에 따라 어떻게 달라지는지 그 반응현상을 3 원 상호작 용효과를 통해서 조사하고자 하였다. 먼저, 본 연구에서 조사 된 변인들의 경향성을 살펴보면 유아의 인지적(cool EF) 실행 기능과 주의집중 문제행동은 여아가 남아보다 점수가 높은 것 으로 나타났다. 이는 여아가 남아에 비해 주의집중 능력이 높 거나 차이가 없다고 보고한 선행연구와는 달리(Barnett et al., 2007; Y. H. Pack, Park, Kim, Sheo, \& Choi, 2019), 비일관적인 성 차를 보고하는 경향(Lange et al., 2014)과 일맥상통한 결과이다.
유아기에 여아의 발달 성숙이 남아보다 더 빠르다는 점을 고려 할 때, 주의집중 문제행동에 대해 보고한 어머니의 기대수준이 반영되어 여아의 주의집중 문제행동 점수가 더 높았을 가능성 을 예측해본다. 또한, 여아의 어머니가 남아의 어머니보다 한 계설정 양육행동을 더욱 많이 하는 것으로 나타났다. 이는 여 아에게 지시나 부드러운 통제와 한계설정과 같은 지도를 더 많 이 한다는 선행연구(Endendijk et al., 2016)와 일맥상통하다. 본 연구에서 남아와 여아별로 어머니의 양육행동과 유아의 실행 기능 간의 상관관계는 예측과 달리 선행연구의 결과와 일치하 지 않는 양상이 나타났다. 남아의 경우 과보호.허용과 거부.방 임 양육행동은 남아의 높은 인지적(cool EF) 실행기능과 관계 했고, 여아의 경우에 거부.방임 양육행동이 높은 인지적(cool $\mathrm{EF})$ 실행기능과 관계가 나타났다. 또한, 인지적(cool EF) 실행 기능과 주의집중 문제행동 간에도 정적인 관계가 나타났다. 이 러한 결과는 인지적(cool EF) 실행기능은 스트레스 상황에 대 한 집중을 피하고, 반추하지 않으며 긍정적인 상황으로 주의를 전환하는 능력(De Lissnyder et al., 2010)이라는 점을 고려할 때, 아직 어린 시기인 유아기에 스트레스 상황을 피하려는 행동과 주의집중을 하지 않는 행동이 구분되지 않아 부모의 보고 내용 
에 반영된 것으로 유추한다. 또한, 실행기능을 측정하는 방법 에 따라서 연구결과가 비일관적으로 나타나고, 어린 연령에서 는 인지적 $(\mathrm{cool} \mathrm{EF})$ 실행기능이 정서적 실행기능에 비해서 성숙 이 느리다는 점(Calson, 2005)에서 비교적 어린 시기에 연구된 본 연구에서 그 관계가 다른 양상으로 나타났을 수 있다.

본 연구의 연구문제인 조절된 조절효과에 대한 주요 결과 를 구체적으로 살펴보면, 유아의 주의집중 문제행동에 대해 성별과 인지적(cool EF), 정서적(hot $\mathrm{EF)} \mathrm{실행기능과} \mathrm{상호작용}$ 하여 유의미한 영향을 미친 어머니의 양육행동은 한계설정, 거부방임, 과보호.허용 양육행동이었다. 이러한 영향은 남아 보다는 여아에게서 더욱 강하게 나타났고, 유아의 인지적(cool $\mathrm{EF}$ ) 혹은 정서적(hot $\mathrm{EF}$ ) 실행기능 수준에 따라 양육행동의 영 향이 달라지는 것을 확인하였다. 첫째로, 여아의 인지적(cool $\mathrm{EF}$ ) 실행기능이 높을 때 어머니가 한계설정 양육행동을 많이 할수록 오히려 여아의 주의집중 문제행동이 증가하는 현상이 나타났다. 즉, 여아의 높은 수준의 인지적 $(\mathrm{cool} \mathrm{EF})$ 는 한계설정 양육행동에 대해서 민감하게 반응하여 한계설정 양육을 적게 받을 때에는 주의력 문제행동이 남아보다 낮지만, 한계설정 양육을 많이 받게 되면 남아보다 주의력 문제행동이 높아지게 되는 차별적 민감성(differential susceptibility)을 보였다. 또한, 여아는 인지적(cool EF) 실행기능이 낮을 때에는 한계설정 양 육이 주의집중 문제행동을 낮추는 긍정적인 영향을 미치지만, 여아의 인지적(cool EF) 실행기능이 높은 경우에는 긍정적이 기 보다는 오히려 주의집중 문제행동을 증가시키는 역효과가 나타났다.

둘째로, 여아의 인지적(cool) 실행기능이 높은 경우 어머니 가 거부 · 방임 양육행동을 하면, 여아의 주의집중 문제행동이 오히려 감소되는 현상이 나타났다. 이러한 유아의 인지적(cool $\mathrm{EF})$ 실행기능의 조절효과는 인지적(cool EF) 실행기능이 높은 수준인 여아에게서만 나타났다. 또한, 인지적(cool EF) 실행기 능이 낮거나 중간정도인 남아의 경우 거부 · 방임 양육을 많이 받으면 같은 수준의 실행기능을 보이는 여아에 비해서 주의 력 문제행동이 증가하는 것으로 나타났다. 즉, 인지적 실행기 능이 낮거나 중간 정도인 남아가 거부 - 방임 양육행동에 대해 부정적인 민감한 반응이 나타나 주의집중 문제행동을 유발하 고, 인지적 실행기능이 높은 여아는 거부 · 방임 양육행동에 대 해 긍정적으로 민감하게 반응하여 오히려 역으로 주의력 문제 행동이 완화되는 현상이 나타났다. 인지적(cool EF) 실행기능 은 억제 통제, 작업기억과 관련되며 정서가 유발되지 않는 상 황에서의 인지적인 유연성을 의미한다(Zelazo \& Cunningham, 2007). 게다가, 여아는 남아에 비해서 잦은 처벌을 회피하고,
스트레스 상황을 벗어나 전환하는 능력이 높은 성차가 나타난 다(Grisson \& Reyes, 2019). 이 두 가지의 특성을 고려했을 때, 어 머니의 한계설정 양육이 일반적으로는 긍정적인 영향을 미치 고, 거부·방임 양육이 부정적인 영향을 미치지만, 처벌이나 지 시, 스트레스 상황을 회피하고 억제하는 특성이 높은 여아에게 는 한계설정과 같은 개입이 통제로 여겨져 여아의 주의집중을 오히려 방해하고(Kamza et al., 2016), 여아에게 혼자 해결하는 시간을 제공하고 내버려 두는 방임적 양육행동이 주의집중을 더 할 수 있도록 돕는 효과가 나타난 것일 수 있다. 본 연구에서 조사한 거부.방임 양육행동의 문항이 "나는 아이가 혼자서 놀 게 내버려둔다.”, "나는 아이가 놀아달라고 하면 다른 일을 핑 계로 혼자 놀게 한다.", "아이에게 성을 내거나 큰소리칠 때가 많다.” 등의 포함되었다. 따라서, 후속연구를 통해 반복검증이 필요하고 주의해서 해석해야겠지만, 인지적(cool EF) 실행기능 이 높은 여아의 경우 어머니가 거부.방임 행동을 하는 것에 민 감하게 반응하고, 처벌을 피하기 위해 과제에 집중하는 등 유 연하게 대처하거나 혹은 부모의 개입 없이 내버려 두어진 혼자 있는 시간에는 오히려 다른 스트레스가 없어져 스스로 집중하 는 행동이 증가되는 가능성으로 해석될 수 있겠다. 따라서, 같 은 양육행동이라도 자녀의 성과 실행기능의 특성에 따라 주의 집중 문제행동이라는 특정 영역에 대해서 다른 양상으로 영향 을 미칠 수 있다는 점을 고려해야 함을 시사한다.

셋째로, 유아의 정서적(hot) 실행기능을 포함한 연구모형 에서 한계설정 양육행동이 주의집중 문제행동을 예방하는 긍 정적인 효과가 여아일 때에는 적지만, 여아의 정서적(hot) 실 행기능이 낮을 때는 한계설정 양육행동에 민감하게 반응하 여 그 긍정적인 영향력이 강해지는 것으로 나타났다. 따라서, 긍정적이라고 알려진 한계설정 양육행동이라도 여아의 인지 적(cool EF) 실행기능이 높을 때와 정서적(hot $\mathrm{EF)} \mathrm{실행기능}$ 이 낮을 때에 그 효과가 달라질 수 있음을 확인하였다. 정서적 (hot $\mathrm{EF)} \mathrm{실행기능은} \mathrm{매력적인} \mathrm{보상을} \mathrm{지연하며} \mathrm{감정적인} \mathrm{반}$ 응과 충동적인 욕구를 누르고 논리적인 사고를 하는 기능이다 (Zelazo \& Cunningham, 2007). 따라서, 욕구를 누르는 능력이 부족한 여아의 경우 부모가 한계설정을 해주고 규칙을 제공해 주는 안정적인 환경에서 더욱 주의집중을 잘하게 되는 것으 로 해석할 수 있겠다. 이러한 점은 이전 선행연구에서 감독과 적절한 개입이 있는 한계설정 양육이 주의집중을 돕고(Ellis \& $\mathrm{Nigg}, 2009)$, 유아의 정서적 실행기능과 한계설정이나 구조화 된 양육이 관계가 있다고 보고한 결과(Hammond et al., 2012) 와 일맥상통한다.

넷째로, 과보호·허용 양육행동이 주의집중 문제행동에 미 
치는 부정적인 영향은 여아의 경우 덜하지만, 여아의 정서적 (hot) 실행기능이 높은 경우에 과보호.허용이 주의집중 문제행 동에 미치는 부정적인 영향이 강해지는 것으로 나타났다. 즉, 여아의 정서적(hot $\mathrm{EF})$ 실행기능이 평균 이상으로 높은 수준 일 때 과보호.허용에 민감하게 반응하여 주의집중 문제행동을 오히려 촉진하는 것으로 나타났다. 이는 과보호.허용 양육을 하는 부모의 양육행동처럼 비일관적이거나 대처기술이 부족 한 양육을 하는 경우 유아의 주의집중을 방해하는 현상을 보 고한 선행연구(Keown \& Woodward, 2002)와 일치한다. 이때, 본인의 욕구를 잘 조절하고 감정적으로 반응하지 않는 여아의 경우, 어머니의 과보호적인 태도는 오히려 주의집중을 방해하 는 것임을 알 수 있다. 여아가 정서적 실행기능이 높을 때에는 어머니의 개입적인 양육이 더욱 부정적으로 작용함을 시사한 다. 종합해보면, 여아의 인지적( $\operatorname{cool} \mathrm{EF})$ 실행기능이 높은 경우 에는 일반적으로 긍정적인 양육으로 알려진 한계설정이 오히 려 부정적으로 작용하기도, 부정적인 양육으로 알려진 거부. 방임 양육행동이 오히려 긍정적으로 작용하였다. 즉, 부모가 한계설정을 많이 할수록 이미 억제 능력이 좋은 여아에게는 자신을 억제하는 성향이 민감하게 반응되어 상황을 쉽게 회피 하도록 학습되어 과제 몰입을 방해할 수 있다. 또한, 거부.방임 을 많이 할수록 스트레스에 대처하기 위해 다른 몰입할 과제 를 찾거나 혼자서 보내는 놀이상황에서 주의집중하도록 훈련 되었을 수 있음을 시사한다. 또한, 여아의 정서적(hot $\mathrm{EF})$ 이 낮 은 경우에는 어머니의 한계설정 양육이 주의집중 문제행동 유 발을 완화시키는 효과가 더욱 강해지고, 정서적(hot $\mathrm{EF})$ 가 높 은 여아에게는 어머니의 과보호.허용 양육이 더욱 위험요인 이 될 수 있다. 본 연구결과는 Grusec과 Davidov (2010)가 아동 의 발달영역 특수적으로 부모의 특정 양육행동의 사회화 효과 가 달라진다고 제안한 현상과 일맥상통하게 부모양육의 영향 은 아동의 주의집중 문제행동이라는 행동영역에 성별과 아동 의 특성(인지적[cool EF], 정서적[hot EF]) 실행기능 발달수준) 에 따라 다르게 나타날 수 있음을 확인하였다. 이로써 일반화 된 긍정적인 혹은 부정적인 양육행동의 보편적인 영향뿐 아니 라 세부화되고 구체적인 잠재된 메커니즘을 이해하는 과정이 중요함을 시사한다. 긍정적인 양육행동이라도 유아의 특성에 따라 더욱 좋게 혹은 더욱 나쁘게 차별적으로 민감하게 반응 하여 다른 영향을 미칠 수 있음을 이해하고, 다양한 접근으로 현상을 해석하는 노력이 필요하다.

그러나, 본 연구결과는 경제수준을 통제하였더라도 비교적 중상층을 대상으로 조사되어 일반화하기에는 무리가 있는 한 계점이 있고, 인지적 $(\mathrm{cool} \mathrm{EF})$ 실행기능과 정서적(hot $\mathrm{EF})$ 실행기
능의 과제를 한 가지씩으로만 측정하였다는 점에서 연구결과 해석을 주의해야 할 것이다. 본 연구의 분석에 포함되지는 않았 지만, 사전분석에서 인지적(cool EF)실행기능과 정서적(hot $\mathrm{EF})$ 와 다른 문제행동(공격성, 위축, 우울 등)과의 관계의 방향성이 부적으로 나타난 것으로 측정에 대한 해석에 문제가 없음을 확 인하였지만, 실행기능이 측정방법에 민감하여 연구결과가 비일 관적으로 나타난다는 점을 고려하여 후속연구에서 다양한 실 험과제를 통해 측정한 연구결과의 반복검증이 필요하다.

이와 같은 한계점에도 불구하고, 본 연구는 상대적으로 정 보가 부족한 유아의 실행기능의 역할을 인지적(cool EF) 실행 기능과 정서적(hot $\mathrm{EF})$ 실행기능으로 구분하여 각기 다른 양상 으로 부모양육행동이 주의집중 문제행동에 미치는 영향을 완 충하거나 촉진하는 것을 밝혔다는 점에서 의의가 있다. 또한, 특정 부모 양육행동마다 유아의 행동에 다르게 영향을 미치며, 유아가 가지는 특성(예: 성별, 실행기능 등의 탄력성 혹은 취약 성)에 따라 다른 메커니즘을 가진다는 점을 확인하며 기존의 연구를 확장하였다. 본 연구결과는 학교진학을 앞둔 유아의 학교준비도를 위해 주의집중 문제행동을 예방하는 부모교육 프로그램 등에서 유아의 실행기능 수준에 따라 그리고 성별에 따라 주의해야 하는 양육행동을 고려하여 가정마다 개별적으 로 접근하는 프로그램 개발의 근거로 활용될 것을 기대한다.

\section{Conflict of Interest}

No potential conflict of interest relevant to this article was reported.

\section{References}

\section{In English}

Achenbach, T. M., \& Rescorla, L. A. (2000). Manual for the ASEABA preschool forms \& profiles. Burlington, VT: University of Vermont, Department of Psychiatry.

Barnett, J. H., Heron, J., Ring, S. M., Golding, J., Goldman, D., Xu, K., \& Jones, P. B. (2007). Gender-specific effects of the catechol-o-methyltransferase val 108/158 met polymorphism on cognitive function in children. American Journal of Psychiatry, 164(1), 142-149. doi:10.1176/ ajp.2007.164.1.142

Beck, D. M., Schaefer, C., Pang, K., \& Carlson, S. M. (2011). 
Executive function in preschool children: Test-retest reliability. Journal of Cognition and Development, 12(2), 169-193. doi:10.1080/15248372.2011.563485

Belsky, J., Bakermans-Kranenburg, M. J., \& van IJzendoorn, M. H. (2007). For better and for worse: Differential susceptibility to envioronmental influences. Current Directions in Psychological Science, 16(6), 300-304. doi:10.1111/j.1467-8721.2007.00525.x

Blair, C., Granger, D., Willoughby, M., Mills-Koonce, R., Cox, M., Greenberg, K. T.,...The FLP Investigators. (2011). Salivary cortisol mediates effects of poverty and parenting on executive functions in early childhood. Child Development, 82(6), 1970-1984. doi:10.1111/j.14678624.2011.01643.x

Blair, C., Mc Kinnon, R. D., \& The Family Life Project Investigators. (2016). Moderating effects of executive functions and the teacher-child relationship on the development of mathematics ability in kindergarten. Learning and Instruction, 41, 85-93. doi:10.1016/j.learninstruc.2015.10.001

Bornstein, M. H., Putnick, D. L., Suwalsky, J. T. D., \& Gini, M. (2006). Maternal chronological age, prenatal and perinatal history, social support, and parenting of infants. Child Development, 77(4), 875-892. doi:10.1111/j.14678624.2006.00908.x

Brock, L. L., Rimm-Kaufman, S. E., Nathanson, L., \& Grimm, K. J. (2009). The contributions of 'hot' and 'cool' executive function to children's academic achievement, learningrelated behaviors, and engagement in kindergarten. Early Childhood Research Quarterly, 24(3), 337-349. doi:10.1016/ j.ecresq.2009.06.001

Carlson, S. M. (2005). Developmentally sensitive measures of executive function in preschool children. Developmental Neuropsychology, 28(2), 595-616. doi:10.1207/s15326942 dn2802_3

Chico, E., Gonzalez, A., Ali, N., Steiner, M., \& Fleming, A. S. (2014). Executive function and mothering: Challenges faced by teenage mothers. Developmental Psychobiology, 56(5), 1027-1035. doi:10.1002/dev.21185

Cole, P. M., \& Deater-Deckard, K. (2009). Emotion regulation, risk, and psychopathology. Journal of Child Psychology and Psychiatry, 50(11), 1327-1330. doi:10.1111/j.1469-7610. 2009.02180.x

De Lissnyder, E. D., Koster, E. H. W., Derakshan, N., \& De Raedt, R. (2010). The association between depressive symptoms and executive control impairments in response to emotional and non-emotional information. Cognition and Emotion, 24(2), 264-280. doi:10.1080/02699930903378354

Diamond, A. (2013). Executive functions. Annual Review of Psychology, 64, 135-168. doi:10.1146/annurev-psych-113011-143750

Eason, S. H., \& Ramani, G. B. (2017). Parental guidance and children's executive fuction: Working memory and planning as moderators during joint problem-solving. Infant and
Child Development, 26(e1982), 1-24. doi:10.1002/icd.1982

Ellis, B., \& Nigg, J. (2009). Parenting practices and attentiondeficit/hyperactivity disorder: New findings suggest partial specificity of effects. Journal of American Academy of Child and Adolescent Psychiatry, 48(2), 146-154. doi:10.1097/ CHI.0b013e31819176d0

Endendijk, J. J., Groeneveld, M. G., Bakermans-Kranenburg, M. J., \& Mesman, J. (2016). Gender-differentiated parenting revisited: Meta-analysis reveals very few differences in parental control of boys and girls. PLoS ONE, 11(7), 1-33. doi:10.1371/journal.pone.0159193

Grissom, N. M., \& Reyes, T. M. (2019). Let's call the whole thing off: Evaluating gender and sex differences in executive function. Neuropsychopharmacology, 44, 86-96. doi:10.1038/s41386-018-0179-5

Grusec, J. E., \& Davidov, M. (2010). Intergrating different perspectives on socialization theory and research: A domain specific approach. Child Development, 81(3), 687-709. doi:10.1111/j.1467-8624.2010.01426.x

Gueron-Sela, N., Bedford, R., Wagner, N., \& Propper, C. B. (2018). Children's executive functions attenuate the link between maternal intrusiveness and internalizing behaviors at school entry. Journal of Clinical Child and Adolescence Psychology, 47(sup1), S435-S444. doi:10.1080/15374416.2 017.1381911

Hammond, S. I., Müller, U., Carpendale, J. M., Bibok, M. B., \& Liebermann-Finestone, D. P. (2012). The effects of parental scaffolding on preschoolers' executive function. Developmental Psychology, 48(1), 271-281. doi:10.1037/00025519

Hayes, A. F. (2017). Introduction to mediation, moderation, and conditional process analysis: A regression-based approach (2nd ed.). New York: The Guilford Press.

Hofmann, W., Schmeichel, B. J., \& Baddeley, A. D. (2012). Executive functions and self-regulation. Trends in Cognitive Sciences, 16(3), 174-180. doi:10.1016/j.tics.2012.01.006

Horn, S. R., Roos, L. E., Beauchamp, K. G., Flannery, J. E., \& Fisher, P. A. (2018). Polyvictimization and externalizing symptoms in foster care children: The moderating role of executive function. Journal of Trauma \& Dissociation, 19(3), 307-324. doi:10.1080/15299732.2018.1441353

Hughes, C., \& Ensor, R. (2009). How do families help or hinder the emergence of early executive function? New Directions for Child and Adolescent Development, (123), 35-50. doi:10.1002/cd.234

Kamza, A., Putko, A., \& Zlotogórska, A. (2016). Maternal parenting attitudes and preschoolers' hot and cool executive functions. Polish Psychological Bulletin, 47(2), 236-246. doi:10.1515/ppb-2016-0028

Keown, L. J., \& Woodward, L. J. (2002). Early parent-child relations and family functioning of preschool boys 
with pervasive hyperactivity. Journal of Abnormal Child Psychology, 30, 541-553. doi:10.1023/A:1020803412247

Lan, X., Legare, C. H., Ponitz, C. C., Li, S., \& Morrison, F. J. (2011). Investigating the links between the subcomponents of executive function and academic achievement: A crossculural analysis of Chinese and American preschoolers. Journal of Experimental Child Psychology, 108(3), 677-692. doi:10.1016/j.jecp.2010.11.001

Lange, K., Thamotharan, S., Sferra, M., Ramos, A., \& Fields, S. (2014). Effects of weight and gender on a task of inattention. Eating Behaviors, 15(4), 574-577. doi:10.1016/j.eatbeh.2014.08.009

Massetti, G. M., Lahey, B. B., Pelham, W. E., Loney, J., Ehrhardt, A., Lee, S. S., \& Kipp, H. (2007). Academic achievement over 8 years among children who met modified criteria for attention-deficit/hyperactivity disorder at 4-6 years of age. Journal of Abnormal Child Psychology, 36(3), 399-410. doi:10.1007/s10802-007-9186-4

Milich, R., Balentine, A. C., \& Lynam, D. R. (2001). ADHD combined type and ADHD predominantly inattentive type are distinct and unrelated disorders. Clinical Psychology: Science and Practice, 8(4), 463-488. doi:10.1093/clipsy.8.4. 463

Murray, K. T., \& Kochanska, G. (2002). Effortful control: Factor structure and relation to externalizing and internalizing behaviors. Journal of Abnormal Child Psychology, 30, 503514. doi:10.1023/A:1019821031523

Nigg, J. T. (2006). Temperament and developmental psychopathology. Journal of Child Psychology and Psychiatry, 47(34), 395-422. doi:10.1111/j.1469-7610.2006.01612.x

Olson, S. L., Bates, J. E., Sandy, J. M., \& Schilling, E. M. (2002). Early developmental precursors of implusive and inattentive behavior: From infancy to middle childhood. Journal of Child Psychology and Psychiatry, 43(4), 435-447. doi:10.1111/1469-7610.00035

Rabiner, D., \& Coie, J. D. (2000). Early attention problems and children's reading achievement: A longitudinal investigation. Journal of the American Academy of Child \& Adolescent Psychiatry, 39(7), 859-867. doi:10.1097/00004583200007000-00014

Riley, E., Okabe, H., Germine, L. Wilmer, J., Esterman, M., \& De Gutis, J. (2016). Correction: Gender differences in sustained attentional control relate to gender inequality across countries. PLoS ONE, 11(11), e0165100. doi:10.1371/ journal.pone.0170876

Ruiz-Ortiz, R., Braza, P., Carreras, R., \& Muños, J. M. (2017). Differential effects of mother's and father's parenting on prosocial and antisocial behavior: Child sex moderating. Journal of Child and Family Studies, 26, 2182-2190. doi:10.1007/s10826-017-0726-4

Sonuga-Barke, E. J. S., Dalen, L., Daley, D., \& Remington, B.
(2002). Are planning, working memory, and inhibition associated with individual differences in preschool ADHD symptoms? Developmental Neuropsychology, 21(3), 255-272. doi:10.1207/S15326942DN2103_3

Tsermentseli, S., \& Poland, S. (2016). Cool versus hot executive function: A new approach to executive function. ENCEPHALOS, 53(1), 11-14.

Willoughby, M., Kupersmindt, J., Voegler-Lee, M., \& Bryant, D. (2011). Contributions of hot and cool self-regulation to preschool disruptive behavior and academic achievement. Developmental Neuropsychology, 36(2), 162-180. doi:10.108 0/87565641.2010.549980

Zelazo, P. D., \& Cunningham, W. (2007). Executive function: Mechanisms underlying emotion regulation. In J. J. Gross (Ed.), Handbook of emotion regulation (pp. 135-158). New York: Guilford.

\section{In Korean}

Kim, H.-S., \& Jeon, J.-S. (2013). The effects of attention ability development program on attention and emotional stability among attention deficit children. The Journal of Korea Open Association for Early Childhood Education, 18(4), 543-562.

Oh, K., \& Kim, Y. (2009). Korean version of the child behavior checklist for age 1.5-5: Parent report form. Seoul: Huno Consulting.

Pack, Y. H., Park, J. E., Kim, D., Sheo, J., \& Choi, N. Y. (2019). The mediating effect of attention deficiency on the relationship between preschool childrens educational electronic media usage time and first-grade childrens academic ability: Multigroup analysis across gender. The Journal of Korea Open Association for Early Childhood Education, 24(1), 451-473. doi:10.20437/KOAECE24-1-18

Park, J., \& Rhee, U. (2001). Children's peer competence: Relationships to maternal parenting goals, parenting behaviors, and management strategies. Korean Journal of Child Studies, 22(4), 1-15.

\section{ORCID}

Jaehee Kim http://orcid.org/0000-0002-3427-9201

Jeeyoung Noh http://orcid.org/0000-0003-4623-8244

Received August 31, 2020

Revision received October 24, 2020

Accepted January 26, 2021 